\title{
The Organic Crisis of the British State: Putting Brexit in its Place
}

\section{Bob Jessop}

Preprint of an article with the same title in Globalizations, 14:1, 133-141

DOI: 10.1080/14747731.2016.1228783 (only differences concern house-style)

\begin{abstract}
:
The Brexit vote was a singular event that is one symptom of a continuing organic crisis of the British state and society and a stimulus for further struggles over the future of the United Kingdom and its place in Europe and the wider world. This crisis previously enabled the rise of Thatcherism as a neoliberal and neoconservative project (with New Labour as its left wing) with an authoritarian populist appeal and authoritarian statist tendencies that persisted under the Conservative-Liberal Democrat coalition (20102015). The 2015 election of a Conservative Government, which aimed to revive the Thatcherite project and entrench austerity, was the immediate context for the tragicomedy of errors played out in the referendum. The ensuing politics and policy issues could promote the disintegration of the UK and, perhaps, the EU without delivering greater political sovereignty or a more secure and non-balkanized place for British economic space in the world market.
\end{abstract}

\section{Introduction}

There is a key difference between the conjuncture that enabled the rise of Thatcherism and the Brexit conjuncture. The former was a rassemblement of the establishment, 'the fusion of an entire social class under a single leadership, which alone is held to be capable of solving an overriding problem of its existence and fending off a mortal danger' (Gramsci 1971: 211; Q13§23: 1604). This was supported by key sections of the middle and working classes (for a good recent analysis, see Gallas 2015). Mrs Thatcher's Conservative party mobilized a new cross-class alliance against those identified with the post-war social democratic settlement and its alleged failures (cf. Hall, Jefferson, Critcher, Clarke, and Roberts 1978; Jessop, Bonnett, Bromley, and Ling 1988). In contrast, the Brexit conjuncture reflected a long-running split in the establishment, a worsening representational crisis in the party system, a growing crisis 
of authority for political elites, a legitimacy crisis of the state, and a crisis of nationalpopular hegemony over the population. Specifically, we can note:

- Entry into and continued membership of the EU have proved a neuralgic point in British politics, dividing imperial nostalgists, nationalists, Atlanticists, Europeanists, and globalists from the 1950s onwards in different ways at different times;

- A growing disconnect between the natural governing parties in Westminster, their members and their voters was reflected most recently in support for Scottish Nationalism and the United Kingdom Independence Party (UKIP);

- The loss of respect for the ruling classes (e.g. for corruption, cronyism, sleaze) and a loss in confidence among the ruling classes, enabled the disgruntled masses to enter politics as an autonomous force, moving from passivity to making radical demands for change that were countered by populist appeals;

- A legitimacy crisis as successive neoliberal projects failed to deliver nationwide prosperity and, in addition, created conditions for fisco-financial crisis.

These and other factors led David Cameron, the Conservative party leader and Prime Minister, into errors of judgement in an attempt to defuse internal party dissent and undermine popular support for UKIP, exposing his party (and the country) to 'an uncertain future by demagogic promises' (Gramsci 1971: 210; Q13§23: 1603). Cameron did not expect to have to fulfil them-initially because he did not anticipate winning a parliamentary majority and then because he thought the politics of fear would produce a victory like that in the Scottish referendum. The problem with this tactic was that the power bloc had lost control over public opinion, the hinge between political and civil society, regarding the European Union. This resulted from decadeslong hostility from what became the pro-Brexit press, which accounted for $82 \%$ of hard copy and on-line readers and would normally support the Conservative party in elections even when positioning itself to the right at other times. Another crucial factor in swinging public opinion in these uncertain times was the alliance of those 'charismatic men of destiny', Nigel Farage (populist leader of UKIP) and Boris Johnson (the high-profile Conservative Mayor of London) (cf. Gramsci 1971: 210; Q13§23: 1603). 


\section{Conjunctural Shifts}

Before turning to its aftermath, we should look beyond the immediate political situation and particular political conjuncture in which the referendum occurred to the wider domestic and international contexts. The integral economic context domestically was a protracted crisis of Britain's flawed post-war Fordist economy and, relatedly, of its insertion into the circuits of Atlantic Fordism and the world market, evident from the mid-1960s onwards. Politically this was associated with a crisis in the state form and state strategies. This crisis occurred because the state lacked the capacities to engage in statist intervention, or effective corporatist coordination, or a consistently rigorous laissez-faire line and therefore oscillated uneasily among different strategies that all failed in their different ways in different conjunctures (see Jessop et al., 1988).

Two general exit strategies from the crisis in/of Atlantic Fordism have been advocated: the knowledge-based economy (KBE), which became the hegemonic economic imaginary from the mid-1990s in Europe and elsewhere; and financialization, which relies less on Fordist wage-led growth or post-Fordist innovation- and knowledgedriven growth than on a debt-fuelled dynamic that favours interest-bearing capital rather than, as with Fordism and the KBE, profit-producing capital (see further, Lavoie and Stockhammer 2013; Sum and Jessop, 2013: 235-95, 395-439). Despite the lipservice paid to the KBE in governing circles, financialization became dominant through the pursuit of neoliberalism from 1975 onwards. Successive governments stressed the inevitability, desirability, and overall benefits of neoliberal globalization and promoted the interests of capital over labour in an open economy. As pursued in the UK, neoliberalism is a relatively coherent and mutually reinforcing set of policies-which is not as such a guarantee that they will succeed (for an analysis of their inherent contradictions and their effects, see Jessop 2015). These policies privilege opportunities for monetary profit over the provision of substantive use-values that meet social needs, facilitate human flourishing, protect the environment, and safeguard planet earth. In particular, they privilege interest-bearing capital and transnational profit-producing capital over other fractions of capital and the interests of subaltern classes, marginal communities, and oppressed social categories. In the UK, such privileging goes well beyond support for the commercial and financial dominance of the City of London as it operated until its deregulation in the mid-1980s. They promote 
it as the leading international centre for international financial capital. Thanks to 'light touch regulation', these policies have made the City the home for many of the most egregious financial scandals in 2007-2015, regardless of the nationality or primary seat of the financial institutions involved. Together with growing inequalities of wealth and income, this is one factor in the loss of respect for financial elites.

More generally, financial claims on the 'real' economy have grown as industrial productivity and output have failed to keep pace with financialization-creating a spurious and unsustainable debt-fuelled boom based on fictitious credit. This has increased the mass and share of profits going to interest-bearing capital at the expense of profit-producing capital that creates internationally tradable commodities. The same profit-oriented logic tends to polarize wealth and income and degrade social cohesion as well as generate financial crises. The ever more visible polarization of wealth and income, noted increasingly even in neoliberal circles as a major economic, social, and political problem, is generating popular discontent and corresponding measures to monitor the population, insulate government from popular demands for economic and social justice, encourage divide-and-rule tactics to this end, and, where necessary, repress dissent.

The neoliberal policies pursued by the Thatcher government and its successors have also reinforced de-industrialization and, where core industries survived, contributed to their balkanization. Successive governments declared Britain to be 'open for business' (and takeover), leading to competing and uncoordinated ties to foreign capital, including, recently, Chinese, Indian, and Russian interests alongside 'the usual suspects'. Without the economic, political, and social bases for a concerted national economic strategy, Britain's economic fortunes came to depend heavily on the vagaries of finance-dominated accumulation and the wider world market and a lowskill, low-tech, low-wage, and even zero-hour service sector associated with a neoliberal race to the bottom. This economic configuration remains as a major structural constraint on efforts to take back control over the future of the British economy. Neoliberal policies and public investment decisions (including the regional allocation of infrastructure projects) also intensified uneven development to the benefit of London and the rest of the South-East—regions that, against the post-referendum 
received wisdom, cast more Brexit votes than the 'Labour heartlands' in northern England (Williams 2016).

Overall, the combination of weak state capacities in the period of flawed post-war economic expansion and the subsequent pursuit of neoliberal strategies has produced a seriously weakened 'real economy' and hypertrophied rent-seeking financial sector. Thus, successive governments have failed to provide adequate technical and vocational training to address labour shortages, protect worker and union rights to limit the race to the bottom and spur productivity-boosting capital investment, encourage research and development to promote the $\mathrm{KBE}$, overcome the housing crisis and reduce the unproductive 'housing sector borrowing requirement', fund the National Health Service rather than the military-industrial complex, moderate uneven regional development, and so on. This failure is partly intellectual as well as structural. It reflects the dominance of a 'money concept of capital' associated in ideal-typical terms with interest-bearing capital over a 'productivist concept of capital' that corresponds to the profit-producing capital (on 'concepts of capital', see Overbeek 1990; on fractions of capital and their implication in industrial and financial crises, see Marx 1894/1967).

This meant that the social bases of economic and political power have come to rest on the fragile foundations of popular capitalism, authoritarian populism, and a selfdisciplinary entrepreneurial culture. The aspirational 'one nation' Keynesian Welfare National State based on jobs for all and social welfare was replaced by a more explicitly 'two nations' project. This promoted popular capitalism, especially home ownership, and 'privatized Keynesianism' (i.e. borrowing to support consumption despite declining real incomes) to curry electoral popularity at the expense of investing in long-term competitiveness based on export-oriented productive investment. It benefitted the 'have lots', produced a divided and ruled squeezed middle class of 'haves', and expanded the 'have not' population. And it has intensified 'north-south' and other regional and local inequalities (including inside major cities). Combined with representational and political crises, this conjuncture was both a threat and an opportunity for the neoliberal project. The measures taken by New Labour aimed to bail out the financial sector and, as a result, transformed a financial crisis into a fiscal crisis marked by rising public sector deficits that were ruthlessly exploited by the Conservative Party, the City of London, and right-wing press to discredit New Labour's 
hard-won reputation for economic competence. It also provided the excuse to move beyond the politics of austerity towards a 'state of enduring austerity' (on the austerity state, see Jessop 2016; Seymour 2014). Given her initial rhetorical critique of the economic and social injustices of past policies, it remains to be seen whether this state form will survive under Mrs May's premiership (see further below).

\section{The Eurozone Crisis}

The international context was an economic and financial crisis in the European Union, notably in the Eurozone, the intensifying democratic deficit in its political institutions, the hegemony of Germany in Northern Europe and its domination over Southern Europe, the economic migration and refugee crises, and, beyond Europe, the shift of the global centre of economic gravity to East Asia. These factors reinforced the view that British sovereignty was being sacrificed to European political institutions even though the real loss of sovereignty was more temporal than territorial and rooted in the space of flows and the power of transnational capital rather than formal juridicopolitical relations among national states.

The Eurozone crisis was triggered in part by contagion effects rooted in the transnational integration of credit relations; these effects were especially evident in the purchase by European financial institutions of toxic asset-backed securities. Contagion was mediated through a general liquidity crisis, the exacerbation of 'global imbalances', and decline in world trade. There were also home-grown features, including a Ponzi-finance-induced recession linked to housing bubbles in Southern Europe and the Irish Republic as well as the crisis of competitiveness in several EU economies. The EU was increasingly organized along neoliberal lines, with its competitiveness, stability, growth, economic governance, and fiscal pacts (Stützle 2013). There are established crisis-management responses for liquidity crises, speculative bubbles, and challenges of national competitiveness. More important in generating the Eurozone crisis is the 'incompossible dream' of a European Monetary Union without stronger fiscal and political integration. This could not address the strong national divergences among accumulation regimes, modes of regulation, social power constellations, and economic imaginaries in the EU. These problems were masked by a short-term boom as credit flowed from Northern to Southern Europe following 
adoption of the euro. But contagion effects of the North Atlantic Financial Crisis interacted with these basic structural flaws to destabilize the Southern European economies, which may not exit the Eurozone and cannot boost exports in a weakened world market. The result has been a debt-default-deflation trap reinforced by capitalist market forces, home-grown as well as contagious austerity intended to bring about internal devaluation, and conditionalities and sanctions imposed by the Troika. The latter comprises the European Central Bank, European Commission, and International Monetary Fund (IMF), which are jointly tasked with imposing and monitoring the conditions for sovereign bailouts in the Eurozone. This has reinforced tendencies towards neoliberal authoritarianism that combines surveillance with pre-emptive policing to limit, stifle, or block popular resistance (Bruff 2013; Oberndorfer 2015; Seymour 2014). Overall, the burden of adjustment is falling on subaltern groups everywhere, especially in Eurozone deficit countries. This benefits the dominant transnational profit-producing and interest-bearing capital fractions and the geopolitical interests of leading member states and their transatlantic allies. Recent research reports by IMF research staff (e.g. IMF 2015; Ostry, Loungani, and Furceri 2016) and its Office of Internal Evaluation (Independent Evaluation Office of the International Monetary Fund 2016) now recognize the folly of this approach, especially for Greece, although such recurrent admissions clearly have limited impact on those who actually make and enforce policy (for a critique, see Varoufakis 2016).

\section{Implications for the Referendum}

The dominance of neoliberalism indicates that the choice posed in the referendum was misleading: the real choice should have been in or out of neoliberalism rather than in or out of the European Union. As posed, the choice was ill-defined:

... the question to be voted on offers two choices 'Stay or Leave' without any clue whatsoever about how either choice would be implemented. 'Stay' might seem a simple default choice, but its consequences would depend on the future evolution of an EU already in crisis and heading for major changes with quite unpredictable effects. And 'leave', as we all now can see, has so many possible variants that no consensus either on which variant would be chosen or on its effects would be conceivable. (fosforos 2016) 
A choice for entry or exit would not affect the overall dominance of neoliberalismonly its specific form and mediations. A remain vote would have consolidated an authoritarian neoliberal Conservative regime committed to enduring austerity; the Brexit vote might produce a J-curve depression with eventual recovery below longterm trend-line growth, at best, with secular stagnation or long-term depression and more austerity as the more likely outcome. The crucial issue that remained largely unvoiced was that real or imagined crisis symptoms were not caused by membership of the European Union as such. Rather, they were rooted in its neoliberal form, the crisis of Eurozone crisis-management, and the long-run failure to address crucial domestic issues that undermined economic and extra-economic competitiveness.

Similar problems were evident in the conventional wisdom around the referendum. For, as Zoe Williams noted, there was no effective challenge to assumptions such as

people who oppose free movement will always oppose it; that it is pointless explaining the lump of labour fallacy, because that is yet more elitist sneering; that public services are under pressure because of foreigners rather than underfunding; that housing is expensive because of demand rather than rent extraction by a capital class empowered by inequality; that the voters have spoken, and now our humanitarian duties to refugees must come second, to the point that we don't even mention them; that the metropolitan elite must simply accept that it let immigration get out of control and must pay the price of a mistrust of unknowable proportions and unguessable length. (Williams, 2016)

\section{What Next?}

There has been a measure of political recovery by the power bloc since the shock generated by the largely unexpected $51.9 \%$ vote in favour of Brexit. As Gramsci observed regarding earlier crisis conjunctures:

The traditional ruling class, which has numerous trained cadres, changes men and programmes and, with greater speed than is achieved by the subordinate classes, reabsorbs the control that was slipping from its grasp. Perhaps it may 
make sacrifices . . but it retains power, reinforces it for the time being, and uses it to crush its adversary. (1971: 210-211; Q13§23)

This can be seen in the speed with which the Conservative Party selected its new leader to preside over a government now morally obliged to take Brexit forward. At issue now is how the ruling class and governing elites will use this power to defend the interests of dominant fractions of national and transnational capital while keeping a divided public content with the speed and outcome of Brexit negotiations. The UK's activation of Article 50 of the Lisbon Treaty, which is required to trigger formal exit negotiations, has been postponed-possibly beyond the French and German elections in 2017, with potential connivance from their current governments. This enables economic, financial, and political elites to concur with Mrs May that 'Brexit means Brexit' while buying time to establish the machinery of government and state capacities to negotiate and then implement new treaties and trade agreements (Rutter and McRae 2016). The civil service count is at its lowest for decades, but the state needs to expand to deal with these complexities, prepare the necessary legislation, and expand its independent diplomatic service. The Secretary of State for Exiting the European Union (colloquially known as the Minister for Brexit), David Davis, has failed so far to mobilize resources from other Whitehall departments, each of which is setting up its own internal Brexit teams. This is likely to fragment pursuit of the Brexit project due to divergent departmental economic sponsorship interests and other commitments regarding Europe and the wider world.

It is also proving hard to recruit the treaty and trade experts needed to negotiate Brexit because trade negotiation was transferred to the EU. At the time of writing (August 2016), Whitehall has only 20 experienced trade negotiators compared with 600 in the European Commission. Other experts work for corporate consultancies and law firms, which can expect lucrative Brexit business on their own behalf. This could well reinforce the neoliberal imaginary-especially as the City of London is likely to seek special privileges to preserve the 'passporting' arrangements that enable firms registered in the UK to offer services throughout the European Economic Area. At least two devolved governments also have policies that conflict with those of central government. Scotland may hold another independence referendum and Northern Ireland, which shares a land border with the Irish Republic, may seek reunification. In 
short, the crisis of the state continues in the United Kingdom and this is compounded by the continuing crisis of multi-spatial metagovernance in Europe.

The representational crises that contribute to Britain's organic crisis have been exacerbated by the Brexit vote. This can be seen in the Conservative Party itself; the toxic split between the Blairite rump of the Parliamentary Labour Party and the wider party membership, which has several features of a social movement rather than a natural governing party; debates over the future of UKIP, which could reposition itself to capture northern working class votes, especially when it loses its place inside the European Parliament and wider European Union; and in electoral and other struggles between rival tendencies and parties in Scotland over its status in the UK and Europe.

The legitimacy crisis is also still present and could worsen if public opinion, spurred on by the pro-Brexit press, becomes dissatisfied with progress and suspects a deliberate policy of backsliding on the part of government. A different but related danger is that continued efforts to protect City interests, maintain the politics and policies of austerity, or, more generally, a slowing economy lead to reduced financial and political support for tackling uneven development, especially through the Northern Powerhouse and Midlands Engine. These rival regional imaginaries with their respective centres of economic gravity in Manchester and Birmingham are unlikely to attract sufficient funds without more intense industrial policy initiatives and increased budgets. Failure to deliver would be a further source of popular resentment. The legacy of a balkanized UK economy will also provide obstacles to take back control over the economic destiny and rebalance the conditions for sustainable recovery. In the increasingly unlikely event of the adoption of the Transatlantic Trade and Investment Pact, it would become even clearer that sovereignty is disappearing.

\section{Conclusions}

The preceding remarks might seem to lend support to the approach to Brexit associated with Jeremy Corbyn, leader of the Labour Party during the referendum campaign, namely, 'remain and reform'. In general terms, not necessarily those of the remain currents in the Labour Party, this would have involved popular struggles to overcome the democratic deficit, to extend monetary union to a fiscal union, transfer 
union, and solidarity union that included the United Kingdom among its members, and a move beyond neoliberal strategies to a red-green approach to European and global problems. Such policies provide the ultimate horizon of action and valid and valuable aspirations for future mobilizations but they are not immediately feasible given the inherited structures within the United Kingdom, the European Union, and the broader transatlantic economic region linked to continued US political domination.

Brexit is so polyvalent a notion and so complex a process that its present meaning is hard to define and its future trajectory hard to discern. Over the next two to three years, we are likely to observe a process akin to a three-dimensional chess game with many participants and even more stakeholders playing according to uncertain rules open to contested renegotiation. While the political situation and political scene have clearly been changed by the Brexit referendum outcome, the political conjuncture is still shaped by the double helix formed by the inherited structural constraints and the organic crisis of the British state and society and analogous phenomena in the European Union. This remark does not justify defeatism, fatalism, or cynical opportunism over the next few years-although these reactions will certainly occur in some circles. It does call for a realistic conjunctural analysis oriented to moving from the search for tactical victories within a period where the left has long been on the strategic defensive in the face of a protean neoliberalism that, as Peck (2010) observed, tends to fail forward. This strategic reorientation requires shifting the balance of forces through popular mobilization combining social movements and party organization and conducted over different spatio-temporal horizons of action with a view to pursuing an offensive strategy for fundamental reform of the European Union and its place within a world society threatened by a triple crisis-economic, energy, and environmental - as well as the tensions and conflicts created by geopolitical rivalries and local oppression.

\section{Acknowledgements}

The author thanks Jamie Morgan for the invitation to contribute to this forum on Brexit and, with the usual and necessary disclaimers, for his excellent and well-informed comments on the first draft of this article. The influence of Antonio Gramsci and Nicos Poulantzas should also be evident to attentive readers. 


\section{Funding}

This article was written while I was in receipt of Economic and Social Research Council funding in the context of the WISERD-Civil Society programme at Cardiff University [award: ES/L009099/1].

\section{References}

Bruff, I. (2013). The rise of authoritarian neoliberalism. Rethinking Marxism, 26, 113129.

fosforos. (2016). Comment on Naked Capitalism website. Retrieved August 3, from http://www.nakedcapitalism.com/2016/08/brexit-realism-maybe-voters-were-notdumb.html\#comment-2647912

Gallas, A. (2015). The Thatcherite offensive: A neo-Poulantzasian analysis. Leiden: Brill.

Gramsci, A. (1971). Selections from the prison notebooks. London: Lawrence and Wishart.

Gramsci, A. (1975) Quaderni del carcere, 4 volumes, Turin: Einaudi.

Hall, S., Jefferson, T., Critcher, C., Clarke, J., and Roberts, B. (1978). Policing the crisis: Mugging, the state and law and order. London: Macmillan.

Independent Evaluation Office of the International Monetary Fund. (2016). The IMF and the crises in Greece, Ireland, and Portugal. Washington, DC: IMF.

International Monetary Fund. (2015). Greece: Preliminary draft debt sustainability analysis (IMF Country Report No. 15/165).

Jessop, B. (2015). Margaret Thatcher and Thatcherism: Dead but not buried. British Politics, 10 (1), 16-30.

Jessop, B. (2016). The heartlands of neoliberalism and the rise of the austerity state. In S. Springer, K. Birch, and J. MacLeavy (eds), The handbook of neoliberalism (pp. 410-421). London: Routledge.

Jessop, B., Bonnett, K., Bromley, S., and Ling, T. (1988). Thatcherism: A tale of two nations. Cambridge: Polity.

Lavoie, M., and Stockhammer, E. (2013). Wage-led growth: Concept, theories and policies. In M. Lavoie and E. Stockhamme (eds), Wage-led growth: An equitable strategy for economic recovery (pp. 13-49). Basingstoke: Palgrave-Macmillan. 
Marx, K. (1894/1967). Capital, vol. 3: The process of capitalist production as a whole. London: Lawrence and Wishart.

Oberndorfer, L. (2015). From new constitutionalism to authoritarian constitutionalism. In J. Jäger and E. Springler (eds), Asymmetric crisis in Europe and possible futures (pp. 184-205). London: Routledge.

Ostry, J. D., Loungani, P., and Furceri, D. (2016). Neoliberalism oversold? Finance and Development, 53(2), 38-41.

Overbeek, H. (1990). Global capitalism and Britain's decline: The Thatcher decade in perspective. London: Unwin and Hyman.

Peck, J. A. (2010). Constructions of neoliberal reason. New York, NY: Oxford University Press.

Rutter, J., and McRae, J. (2016). Brexit: Organising Whitehall to deliver. Briefing paper. London: Institute for Government.

Seymour, R. (2014). Against austerity: How we can fix the crisis they made. London: Pluto.

Stützle, I. (2013). Austerität als politisches Projekt [Austerity as a political project]. Münster: Westfälisches Dampfboot.

Sum, N.-L., and Jessop, B. (2013). Cultural political economy: Putting culture in its place in political economy. Cheltenham: Edward Elgar.

Varoufakis, Y. (2016). IMF confesses it immolated Greece on behalf of the Eurogroup. Retrieved July 7, from https://yanisvaroufakis.eu/2016/07/29/the-imf-confesses-itimmolated-greece-on-behalf-of-the-eurogroup/

Williams, Z. (2016). Think the north and the poor caused Brexit? Think again. Guardian. https://www.theguardian.com/commentisfree/2016/aug/07/north-poorbrexit-myths 